\title{
A Facile Synthesis and Characterization of new Nitrogen, Phosphorus, Potassium (N-P-K) Fertilizer Fortified with Tri-micronutrient Matrix and its application for Optimal Plant Augmentation
}

\author{
N. V. S. VENUGOPAL ${ }^{1 *}$ and G. N. V. MOHANA RAO ${ }^{2}$ \\ 1,2Department of Chemistry, Institute of Science, GITAM University Visakhapatnam-530045, \\ Andhra Pradesh, India. \\ ${ }^{*}$ Corresponding author E-mail: vnutulap@gitam.edu \\ http://dx.doi.org/10.13005/ojc/370626
}

(Received: October 18, 2021; Accepted: December 14, 2021)

\begin{abstract}
At present in agricultural techniques engaged the optimal nutrient supply is very imperative factor for elevated crop yield and all essential plant macro and micronutrients. Micronutrients play vital role in photosynthesis. For balanced crop nutrition micronutrient support is essential. Micronutrient fertilizer required in small quantities by plants and occupy vital role in physiology of plant kingdom. Proven fact is decisive plant functions are over involved if enough micronutrients are engaged. In this paper the author developed a new N-P-K fertilizer fortified with tri-micronutrient matrix and its application for optimal Plant growth. The author developed and analyzed hundred percent water soluble active fertilizer(15-15-15) with three important micronutrients (-3.4 0.5\% Zn, 0.5\% Fe, 0.5\% $\mathrm{Mg}$ ). Pot experiments were conducted with and without proposed fertilizer on Solanum lycopersicum (tomato) seeds. The proposed enhanced efficiency fertilizer with tri-micronutrient matrix showed better plant growth as compared to normal untreated fertilizer in low nutrient soil field.
\end{abstract}

\section{Keywords: Nitrogen, Phosphorus, Potassium fertilizer, Micronutrient matrix Pot experiments, Plant growth, Solanum lycopersicum seeds.}

\section{INTRODUCTION}

Food security is one of the world's big challenges with huge demand forecast. Every year a series of agricultural products, drink and food products for human consumption and animal feed are formed. Climatic conditions and total geography have big impact on agricultural use of available land. Various materials added to the soil in order to supply different chemical elements for better soil fertility. Fertilizers are needed for receiving increase in crop growth and yield. Macronutrients such as Nitrogen, Phosphorous and Potassium were recognized for the supply of important nutrients to all crops. At present more chemical fertilizers used by farmers to produce higher yield and augment reasonable efficiency. The use efficiency of N-P-K is about $30-60 \% ; 30-50 \%$ and $10-20 \%$, respectively and these reflect low macronutrients use efficiency for crops. The fertilizers not in use by crops instead

This is an Open Access article licensed under a Creative Commons license: Attribution 4.0 International (CC- BY). Published by Oriental Scientific Publishing Company @ 2018

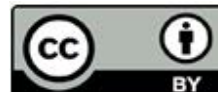


entering in to the environment is the pressing concern to the world.

Visual symptoms on crops always reveal micronutrients deficiency and it can be tested from plant tissues and soil. Micronutrients like Iron, Zinc and Magnesium have important role for plant growth. Iron is very important for biological process and cell growth in plants. The main component of enzymes indispensable for chlorophyll synthesis, photosynthesis etc is Iron. The role of Zinc is vital for plant hormone balance and auxin activity. Magnesium is the central core of the chlorophyll molecule in plant tissue. Shortage of chlorophyll results low plant growth if Magnesium is deficient. Magnesium deficiency leads to boost contribution of production and also diminishes cost-effective efficiency and augments environmental pollution. ${ }^{1-2}$

The recent scenario was in the preparation and application of nanofertilizers. Nanofertilizers help increase the effectiveness of fertilizer, enhance yield and excellence of crops, diminish detrimental effects of chemical fertilizers on environment and develop a green and sustainable agriculture ${ }^{3-12}$. By coating urea into nanofilm (nanourea) has been triumphant using it for Canola ${ }^{13}$. To enhance yield and reduce nitrate leaching, Nano Nitrogen fertilizer synthesized by coating Urea with Sulfur and nano Nitrogen chelate. Nano Nitrogen was effectively applied for potato. The current research in progress by many researchers in the world was to develop Complex NPK nanofertilizer. Wu and Liu investigated the encapsulation of NPK fertilizer into chitosan and coating the outer by poly (acrylic acid-co-acrylamide). Complex NPK nanofertilizer was prepared by trapping the fertilzer in polyacrylic hydrogel and later the study of the NPK slow release control of the nanofertilizer ${ }^{14}$. For loading nutrients to various crops materials like Chitosan and its nanoparticles etc were functional as a useful matrix. Complex NPK fertilizer was encumbered into chitosan nanoparticles, and chitosan nanoparticles with polymethacrylic acid (MMA) ${ }^{15-19}$ Therefore from the past forty years chemical fertilizers have been crucial to the growth of world agricultural production.

\section{MATERIALS AND METHODS}

The various raw materials used in the current study were given in Table 1. All other chemicals used were of analytical grade.
Table1: Raw materials

\begin{tabular}{lccl}
\hline S.no & Materials & $\begin{array}{c}\text { Molecular } \\
\text { formula }\end{array}$ & Grade \\
\hline 1 & Ammonium sulphate & $\left(\mathrm{NH}_{4}\right)_{2} \mathrm{SO}_{4}$ & Fertilizer grade \\
2 & Mono ammonium phosphate & $\mathrm{NH}_{4} \mathrm{H}_{2} \mathrm{PO}_{4}$ & Fertilizer grade \\
3 & Urea & $\mathrm{NH}_{2} \mathrm{CO} \mathrm{NH}_{2}$ & Fertilizer grade \\
4 & Potassium nitrate & $\mathrm{KNO}_{3}$ & Fertilizer grade \\
5 & Chelated Zinc & $\mathrm{Zn} \mathrm{EDTA}^{2}$ & Fertilizer grade \\
6 & Ferrous sulphate & $\mathrm{FeSO}_{4} \cdot 7 \mathrm{H}_{2} \mathrm{O}$ & Fertilizer grade \\
7 & Magnesium sulphate & $\mathrm{MgSO}_{4} \cdot 6 \mathrm{H}_{2} \mathrm{O}$ & Fertilizer grade \\
\hline
\end{tabular}

The above-mentioned raw materials of fertilizers grade were analyzed by using existing methods defined in Fertilizer control order (FCO) procedures to know the nutrient contents accordingly final product formulation prepared. The methods of analysis used for the analysis of raw materials were given in Table 2.

Table 2: Methods of analysis used for the analysis of raw materials

\begin{tabular}{|c|c|c|}
\hline S.no & Parameter & Procedure No \\
\hline \multirow[t]{3}{*}{1} & Ammoniacal nitrogen & FCO 1985 as amended upto \\
\hline & & February 2019, Schedule \\
\hline & & Part-B-3(vii) \\
\hline \multirow[t]{3}{*}{2} & Nitrate nitrogen & FCO 1985 as amended upto \\
\hline & & February 2019, Schedule \\
\hline & & Part-B-3(ix) \\
\hline \multirow[t]{3}{*}{3} & Urea nitrogen & FCO 1985 as amended upto \\
\hline & & February 2019, Schedule \\
\hline & & Part-B-3(xi) \\
\hline \multirow[t]{3}{*}{4} & Water soluble phosphate & FCO 1985 as amended upto \\
\hline & & February 2019, Schedule \\
\hline & & Part-B-4(iii) \\
\hline \multirow[t]{3}{*}{5} & Water soluble potassium & FCO 1985 as amended upto \\
\hline & & February 2019, Schedule \\
\hline & & Part-B-5(ii) \\
\hline \multirow[t]{3}{*}{6} & Sulphate sulfur & FCO 1985 as amended upto \\
\hline & & February 2019, Schedule \\
\hline & & Part-B-24(A) \\
\hline \multirow[t]{3}{*}{7} & Zinc & FCO 1985 as amended upto \\
\hline & & February 2019, Schedule \\
\hline & & Part-B-15 \\
\hline \multirow[t]{3}{*}{8} & Iron & FCO 1985 as amended upto \\
\hline & & February 2019, Schedule \\
\hline & & Part-B-13 \\
\hline
\end{tabular}

\section{Instrumentation}

Inductively coupled plasma optical emission spectrometry(ICP-OES), Perkin-Elmer (Optima7000DV) was preferred for elemental analysis. For macronutrients, Auto analyzer (Skalar) was used. Analytical balance, Top load balance (Sartorius), Hot air oven (Tempo), etc were used in the study. 


\section{METHODS}

All the standard solutions were standardized as per procedure before proceeding to analysis. Performed the calibration to weighing balances and hot air oven at the time of analysis. Blank estimation was performed for all the parameters on the reagents and accordingly correction given to the samples analysis. Duplicate determination was performed for each parameter in the analysis and average was taken as final result.

\section{Preparation of N-P-K fertilizer fortified with tri-micronutrient grade}

Each substance-Mono Ammonium Phosphate, Ammonium Sulphate, Urea, Potassium Nitrate, Zinc EDTA, Ferrous Sulphate hepta hydrate and Magnesium Sulphate hexa hydrate have taken $100 \mathrm{~g}$ grounded individually with help of Mortar and pestle and kept for drying in a vacuum desiccators for 24 hours. after $24 \mathrm{~h}$ the substances are properly kept in self sealed covers to avoid moisture absorption. Three replicate mixtures were prepared separately and each replicate consists of $25.0 \mathrm{~g}$ of Mono Ammonium Phosphate, $19.29 \mathrm{~g}$ of Ammonium Sulphate, $10 \mathrm{~g}$ of Urea, $33.71 \mathrm{~g}$ of Potassium Nitrate, $4.17 \mathrm{~g}$ of Zinc EDTA, $2.63 \mathrm{~g}$ of Ferrous sulphate hepta hydrate and $5.21 \mathrm{~g}$ of magnesium sulphate hexa hydrate. All the mixtures are finely grounded and mixed for $20 \mathrm{~min}$ in a mixer of Preeti make, model no MG 198 (1300 watts) with 4000rpm by using small jar of capacity $700 \mathrm{~mL}$. All the three replicate mixtures are dried in a vacuum desiccators for $24 \mathrm{~h}$ to remove surface moisture absorbed during the preparation process.

\section{RESULTS AND DISCUSSION}

Initially all the raw materials were analyzed and the results are given in Table 3.

Table 3: Raw material analysis

\begin{tabular}{lc}
\hline Name of the raw material & $\begin{array}{c}\text { Percentage } \\
\text { obtained }\end{array}$ \\
\hline Ammonium Sulphate (Ammonical Nitrogen-AN & 20.2 \\
Sulphate sulphur as S & 23.2 \\
Mono Ammonium Phosphate: Ammonical Nitrogen-N & 11.5 \\
Water soluble Phosphate as $\mathrm{P}_{2} \mathrm{O}_{5}$ & 60.2 \\
Urea:Urea nitrogen as N & 46.1 \\
Potassium Nitrate:water soluble as $\mathrm{K}_{2} \mathrm{O}$ & 44.5 \\
Nitrate Nitrogen as N & 12.5 \\
Chelated Zinc-EDTA:as Zn & 12.1 \\
Ferrous sulphate penta Hydrate: Iron as Fe & 19.3 \\
Magnesium Sulphate hexa Hydrate:as Mg & 9.6 \\
\hline
\end{tabular}

A new formulated $100 \%$ water soluble fertilizer with three important micronutrients (15-15$15-3.40 .5 \% \mathrm{Zn}, 0.5 \% \mathrm{Fe}, 0.5 \% \mathrm{Mg}$ ) was developed and analyzed. The N-P-K fertilizer fortified with tri-micronutrient product was shown in Figure 1.

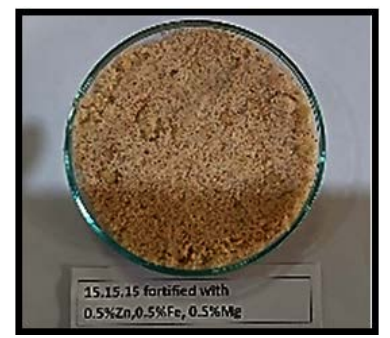

Fig. 1. N-P-K fertilizer fortified with tri-micronutrient Analysis

i) Total Nitrogen and Nitrate nitrogen are analyzed by macro Kjedhal distillation method as per FCO 1985 procedures.

ii) Water soluble Potassium was analyzed by STPB (sodium tetra phenyl boran) method prescribed in FCO1985. For this taken $2.5 \mathrm{~g}$ sample and dissolved in Ammonium oxalate, and from that required aliquot taken and added $2 \mathrm{~mL} 20 \% \mathrm{NaOH}, 5 \mathrm{~mL} \mathrm{HCHO}$ and $25 \mathrm{~mL}$ STPB reagent and made upto $100 \mathrm{~mL}$ mark with distilled water. Filtered through no. 42 Whatman filter paper. $50 \mathrm{~mL}$ filtrate was taken in $150 \mathrm{~mL}$ conical flask titrated against Cetyl trimethyl ammonium bromide. Blank and standard $\mathrm{KH}_{2} \mathrm{PO}_{4}$ determination was also done and accordingly correction given.

iii) Sulphate sulphur was determined in the samples by digesting the samples with Concentrated $\mathrm{HCl}$, filtered and precipitated as Barium sulphate with Barium chloride solution, dried at $250^{\circ} \mathrm{C}$, weighed and calculated as Sulphur.

iv) Ammoniacal nitrogen (AN), Urea Nitrogen (UN), Water Soluble phosphate $\left(\mathrm{P}_{2} \mathrm{O}_{5}\right)$ were analyzed by segmented flow analyzer also called Auto analyzer.

Sample preparation: Three replicates were analyzed for physical parameters, nutrients and heavy metals present in the new proposed fertilizer grade. Known quantity of the sample dissolved in distilled water, 
filtered, and analyzed on segmented flow analyzer (SKALAR SAN++ system).

Principles involved in the analysis on the auto analyzer

\section{AN determination}

The reaction involved is Berthlot reaction in which Ammonia reacts with sodium hypo chlorite in presence of buffer and forms monochloramine which reacts with salicylate to form 5 -aminosalicylate. A green colored complex is formed after oxidation and oxidative coupling which is then measured at $660 \mathrm{~nm}$.

\section{$\mathrm{WSP}_{2} \mathrm{O}_{5}$ determination}

The sample is mixed with ammonium heptamolybdate solution and forms molybdo phosphoric aicd which reacts with metavanadate to form stable yellow coloured vanadomolybdo phosphoric acid, measured at 420nm.

\section{UN determination}

The sample is mixed with diacetyl monoxime at $90^{\circ} \mathrm{C}$, forms coloured complex, which is further intensified by the addition of thiosemicarbazide and an acid reagent is used to increase the rate of colour formation, measured at 520nm.

A combined stock standard solution of 10,000ppm $\mathrm{P}_{2} \mathrm{O}_{5}$, 4000ppm AN, 4660ppm UN prepared by taking appropriate weights of $A R$ grade $\mathrm{NH}_{4} \mathrm{Cl}, \mathrm{KH}_{2} \mathrm{PO}_{4}$, and Urea. From this stock solution, three working standards (S1, S2, S3) prepared, in which $\mathrm{S} 1$ contains 500ppm $\mathrm{P}_{2} \mathrm{O}_{5}$, 233ppm UN, 200ppm AN; S2 contains 1000ppm $\mathrm{P}_{2} \mathrm{O}_{5}, 466 p p m$ UN, 400ppm AN; and S3 contains 1500ppm $\mathrm{P}_{2} \mathrm{O}_{5}$, 699ppm UN, 600ppm AN. Analyzer was calibrated with above 3 working standards in first order reaction mode. Correlation coefficient for all three parameters is above 0.999 and RSD is $<0.01 \%$ (shown in Figure 2, 3 \& 4).

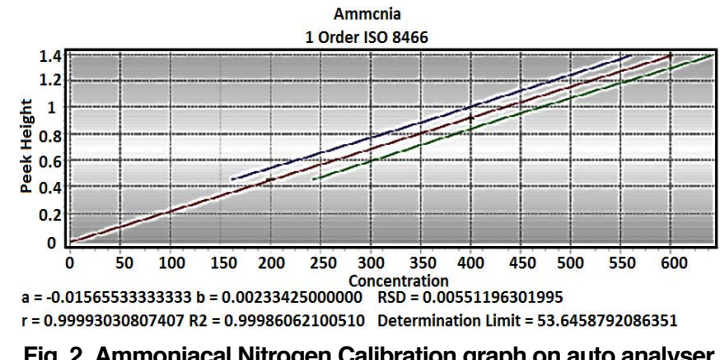

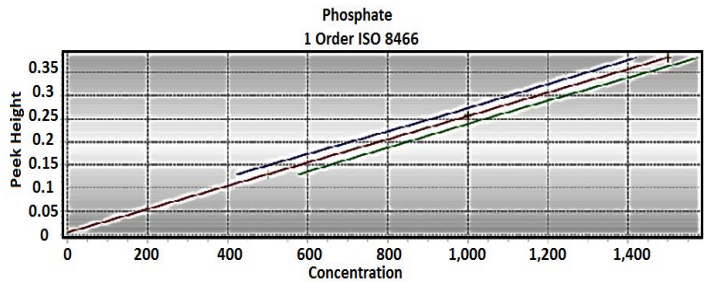

$a=0.00472733333333 b=0.0002516465000000$ RSD $=0.00113940075625$

$\mathrm{r}=0.99995900088291 \mathrm{R} 2=0.99991800344675$ Determination Limit $=103.741148587397$

Fig. 3. Phosphate Calibration graph on auto analyser

$$
\text { Urea }
$$

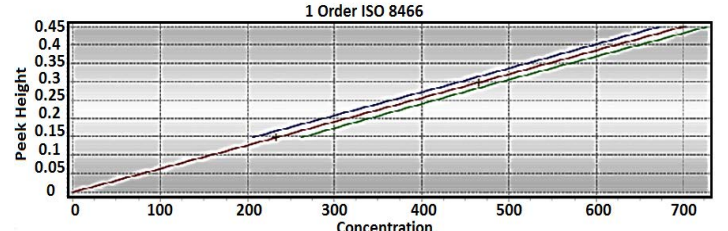

$\mathrm{a}=-0.00098600000000 \mathrm{~b}=0.00064301287554$ RSD $=0.00103057023050$

$r=0.99997634305835 R 2=0.99995268667635$ Determination Limit $=36.9704560821373$

Fig. 4. Urea Nitrogen Calibration graph on auto analyser

v) Micronutrients- $\mathrm{Zn}, \mathrm{Fe}$ and $\mathrm{Mg}$ analyzed on ICP OES (OPTIMA 7000DV).

The samples were strongly digested with $\mathrm{HCl}$ and $\mathrm{HNO}_{3}$ and then diluted with Millipore ultra-pure distilled water (conductivity $<0.1 \mathrm{microsiemens} / \mathrm{cm}^{2}$ ). Calibration was done with three multi element working standards of 10,50,100ppm which were prepared from stock 1000ppm ICP multi element standard solution IV (Merck, certipur). Same acid back ground maintained for working standards used for calibration. The wave lengths selected for analysis of $\mathrm{Fe}$ is $238.204 \mathrm{~nm}, \mathrm{Zn}$ is $213.857 \mathrm{~nm}$ and $\mathrm{Mg}$ is $278.297 \mathrm{~nm}$. Correlation coefficient was above 0.999 and RSD was less than $1.0 \%$.

vi) Heavy metals- $\mathrm{As}, \mathrm{Pb} \& \mathrm{Cd}$ were analyzed on ICP OES (OPTIMA 7000DV).

The samples were strongly digested with $\mathrm{HCl}$ and $\mathrm{HNO}_{3}$ of trace metal grade, then diluted with Millipore ultra-pure distilled water. Calibration was done with three multi element working standards of 0.25,0.5 and $1.0 \mathrm{ppm}$ which were prepared from stock 100ppm ICP multi element standard solution $X$ (Merck, certipur).). Same acid back ground maintained for working standards used for calibration. The wave lengths selected for analysis of As is $188.979 \mathrm{~nm}, \mathrm{~Pb}$ is $220.350 \mathrm{~nm}$ and $\mathrm{Cd}$ is $226.50 \mathrm{~nm}$. Correlation coefficient was observed above 0.999 and RSD was less than $5.0 \%$. 
Table 4: Analysis of N-P-K fertilizer fortified with tri-micronutrient

\begin{tabular}{|c|c|c|c|}
\hline \multirow[t]{2}{*}{ Test parameter } & \multicolumn{3}{|c|}{ Result } \\
\hline & Trail-1 & Trail-2 & Trail-3 \\
\hline Total Nitrogen per cent by weight, minimum & 15.1 & 15 & 15.2 \\
\hline Nitrate nitrogen per cent by weight, minimum & 4.1 & 3.9 & 4.0 \\
\hline Ammoniacal nitrogen per cent by weight, minimum & 6.32 & 6.4 & 6.5 \\
\hline Urea Nitrogen percent by weight, minimum & 4.65 & 4.7 & 4.7 \\
\hline Water Soluble phosphate (as $\mathrm{P}_{2} \mathrm{O}_{5}$ ) per cent by weight, minimum & 15.1 & 15.2 & 15.0 \\
\hline Water soluble potash $\left(\right.$ as $\left.\mathrm{K}_{2} \mathrm{O}\right)$ per cent by weight, minimum & 15 & 15.1 & 15.15 \\
\hline Sulphate sulfur (as S) percent by weight, minimum & 3.5 & 3.5 & 3.53 \\
\hline Zinc as Zn per cent by weight, minimum & 0.53 & 0.5 & 0.52 \\
\hline Iron as Fe per cent by weight, minimum & 0.51 & 0.49 & 0.51 \\
\hline Magnesium as Mg per cent by weight, minimum & 0.51 & 0.5 & 0.50 \\
\hline Moisture per cent by weight, maximum & 0.8 & 0.7 & 0.75 \\
\hline \multicolumn{4}{|l|}{ Heavy metals content } \\
\hline Arsenic as As ppm by weight, maximum & 4.0 & 3.0 & 3.4 \\
\hline Lead as $\mathrm{Pb}$ ppm by weight, maximum & $<1$ & $<1$ & $<1$ \\
\hline Cadmium as Cd ppm by weight, maximum & $<1$ & $<1$ & $<1$ \\
\hline
\end{tabular}

Application of the proposed fertilizer to Solanum lycopersicum seeds

The investigation of Solanum lycopersicum plants under controlled conditions was carried without off-putting effects of various environmental aspects. Pot experiments were conducted with and without the proposed fertilizer. In one pot soil weight of $955 \mathrm{~g}$ and $100 \mathrm{~mL}$ of water and gently mixed and on the top of the soil $0.03 \mathrm{~g}$ of Solanum lycopersicum seeds applied uniformly. In another pot, soil weight of $954 \mathrm{~g}$ and $100 \mathrm{~mL}$ of $1 \%$ proposed fertilizer in water are gently mixed to get uniformity in the soil and on the top of the soil $0.03 \mathrm{~g}$ of Solanum lycopersicum seeds applied uniformly. The growth pattern was shown in Figure 5.

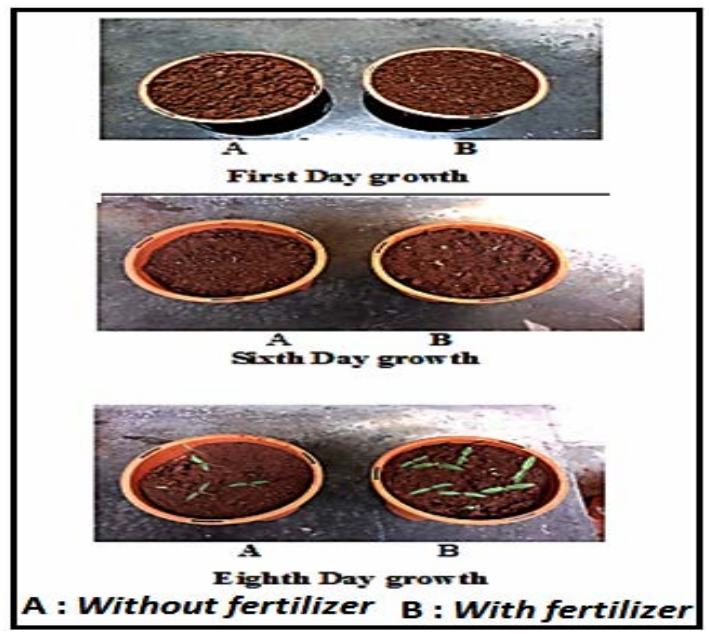

Fig. 5. Growth pattern of Solanum lycopersicum

\section{CONCLUSION}

All crops require important macronutrients such as N-P-K. Fertilizers are crucial to different crops, endow with obligatory nutrients for crop growth, and increase crop yield and quality of the crop. N-P-K fertilizer fortified with tri-micronutrient matrix and its application for optimal Plant growth shown best results and more crop yield. The proposed fertilizer showed better plant growth as compared to normal low nutrient soil field.

\section{ACKNOWLEDGEMENT}

The author wish to thank the management of GITAM (Deemed to be University), Visakhapatnam, Andhra Pradesh, India for supporting this work.

\section{Conflict of Interest}

The authors declare that there are no conflicts of interest. 


\section{REFERENCES}

1. Sun, B.; Zhang, L.; Yang, L.; Zhang, F.; Ambio., 2012, 41, 370.

2. Trenkel, M.M, Controlled release and stabilized fertilizer in agriculture (International Fertilizer Industry Association, Paris., 2010.

3. Corredor, E.; Testillano, P.S.; José Coronado, M.; González-Melendi, P.; FernándezPacheco, R.; Marquina,C.; Ricardo Ibarra, M.; De la Fuente, J.M.; Rubiales, D.; De Luque, A.P.; Carmen Risueño, M.; 2009, BMC Plant Biol., 2009, 9, 1.

4. Ghormade, V.; Deshpande, M.V.; Paknikar, K.M.; Biotechno., 2011, 29, 792.

5. Huang, S.; Wang, L.; Liu, L.; Agron. Sustain. Dev., 2015, 35, 369-400.

6. Khodakovskaya, M.; Dervishi, E.; Mahmood, M.; Xu, Y.; Z. Li, F.; Watanabe, A.S.; ACS Nano., 2009, 3, 322.

7. Liu, R.; Lal, R.; Sci Rep., 2014, 4, 5686.

8. Prasad,T.N.V.K.V.; Sudahka, P.; Sreenivasulu, Y.; Latha, P.;Munaswamy, V.; Raja Reddy, K.; Sreeprasat, T.S.; Panikkanvalappil, S.R.; Thalappil, P.; J. Plant Nutr., 2012, 35, 905.

9. Servin, A.; Elmer, W.; Mukherjee, A.; Hamdi, H.; White, J.C.; Bindranban, P.; Dimkpa, C.,
J. Nanopart. Res., 2015, 17, 92.

10. Tarafdar, J.C.; Raliya, R., Mahawar, H.; Agric Res., 2014, 3, 257-262.

11. Wu, L.;Liu, M.; Carbohydr. Polym., 2008, 72, 240.

12. Zareabyaneth, H.; Bayatvarkeshi, M.; crop Environ. Earth Sci., 2015, 74, 3385.

13. De Rosa, M.C.; Monreal, C.; Schitzer, M.; Walsh, R.; Sultan, Y.; Nanotechnol., 2010, 5, 9.

14. Teodorescu, M.; Lungu, A.; Stanescu,P.O.; Neamtu,C.; Ind. Eng. Chem. Res., 2009, 48, 6527.

15. Corradini, E.; de Moura, M.R.; Mattoso, L.H.C.; Polym. Letters., 2010, 4, 509.

16. Ha, N.M.C.; Nguyen, T.; Wang, H.; Res Chem Intermed., 2019, 45, 51-63.

17. Phelan, P.; Moloney, A. P.; McGeough, E. J.; Humphreys, J.; Bertilsson, J.; O’Riordan, E.G.; O'Kiely, P.; Critical Reviews in Plant Sciences., 2015, 34, 281-326.

18. Garde-Cerdan,T.;Santamaría, P.; RubioBreton, P.; Gonzalez-Arenzana, L.; LopezAlfaro, I.; Lopez, R.; Food Sci. Technol., 2015, 60, 684-689.

19. Fernández-Escobar, R.; Antonaya-Baena, M.F.; Sánchez-Zamora, M.A.; Molina- Soria, C.; Scientia Hortic., 2014, 167, 1-4. 